\title{
Fertigation Methods and N Source on Chili through Drip Irrigation
}

\author{
Metode Fertigasi dan Sumber N pada Cabai Rawit melalui Irigasi Tetes
}

\author{
Anas Dinurrohman Susila ${ }^{1 *}$,Adea Oktavia ${ }^{2}$, and Bartolomeus Varian Yuliharsa Wirabawana ${ }^{3}$ \\ ${ }^{1}$ Department of Agronomy and Horticulture, Faculty of Agriculture, Bogor Agricultural University \\ Jl. Meranti, Kampus IPB Dramaga, Bogor, 16680, Indonesia \\ ${ }_{2}^{2}$ PT Syngenta, CIBIS Nine 6th floor Jl. T.B. Simatupang No. 2 Jakarta 12560, Indonesia \\ ${ }^{3} \mathrm{PT}$. Lautan Luas Tbk. \\ Jl. Ngemplak No. 30 Komp. Ambengan Plaza Blok B/35-37, Surabaya, Jawa Timur 60272, Indonesia
}

Received 28 September 2020/Accepted 9 November 2020

\begin{abstract}
Chili (Capsicum frutescens L.) has an important role in Indonesian cuisine. Conventional crop management with lessefficient fertilizer application was still commonly implemented by farmers; on the other hand, fertilizer application through fertilizer will increase yield and reduce production costs. Research objectives were to find out the best fertilizer application methods through drip irrigation and obtain a nitrogen fertilizer source that can increase polyethylene mulched chili yield. This research was conducted in Inceptisol (Dytropept Fluventik, Isohiperthermik) soil type. The experiment was conducted at Bogor Agricultural University Research Station, Cikarawang, from June to December 2016. The first experiment was arranged in a randomized complete block design (RCBD) with three methods of fertilizer applications: split, drip, and conventional (no fertigation). The second experiment, from March to October 2017, was arranged in $R C B D$, with three $N$ sources (Urea $(46 \% \mathrm{~N}), \mathrm{ZA}(21 \% \mathrm{~N})$, and NPK (16-16-16)\% N-P $\left.\mathrm{O}_{5},-\mathrm{K}_{2} \mathrm{O}\right)$, with four replications. Results showed that split and drip fertigations had no different effect on total and marketable yield; however, the yields of both treatments were higher than that of conventional applications. The second experiment results showed that all $N$ sources did not affect the growth and yield of chili.
\end{abstract}

Keywords: fertilization, nitrogen, micro-irrigation, polyethylene mulch

ABSTRAK

Cabai rawit (Capsicum frutescens L.) memiliki peran penting dalam menu masakan di Indonesia. Pengelolaan tanaman secara konvensional dengan pemupukan yang kurang efisien masih banyak dilakukan oleh petani, sebaliknya pemupukan secara fertigasi meningkatkan hasil dapat dan menurunkan biaya produksi. Penelitian ini bertujuan untuk mengetahui metode aplikasi pemupukan melalui irigasi dan sumber $N$ yang dapat menigkatkan hasil cabai rawit dengan budidaya memakai mulsa plastik. Penelitian ini dilakukan pada jenis tanah Inceptisol (Dytropept Fluventik, Isohiperthermik). Perobaan dilakukan di Kebun Penelitian Institut Pertanian Bogor, Cikarawang. Percobaan pertama pada Juni-Desember 2016 disusun dalam rancangan acak kelompok (RAK), 4 ulangan dengan 3 metode aplikasi fertigasi: split, irigasi tetes, dan konvensional(tanpa fertigasi). Percobaan kedua dilakukan pada Maret-Oktober 2017 disusun dalam RAK dengan empat ulangan dengan perlakuan tiga sumber $\mathrm{N}$ (Urea $(46 \% \mathrm{~N})$, ZA $(21 \% \mathrm{~N})$, dan $\left.\mathrm{NPK}(16-16-16) \% \mathrm{~N}-\mathrm{P}_{2} \mathrm{O}_{5},-\mathrm{K}_{2} \mathrm{O}\right)$. Hasil penelitian menunjukkan bahwa split dan drip tidak memberikan pengaruh yang berbeda terhadap total panen dan hasil panen yang dapat dipasarkan, namun keduanya lebih tinggi dari hasil panen dengan konvensional. Hasil percobaan kedua menunjukkan bahwa semua sumber $N$ tidak berpengaruh terhadap pertumbuhan dan hasil panen cabai.

Kata kunci: irigasi mikro, nitrogen, mulsa plastik, pemupukan

\section{INTRODUCTION}

Chili is an important national commodity that needs attention because an increase in Chili prices can contribute to economic inflation. The planting areas of Indonesian

* Corresponding author. e-mail: anasdsusila10@gmail.com chili in 2017 was 269,806 ha, with a total production of $1,153,157$ tons. The productivity of red chili is 6.37 ton ha $^{-1}$ and chili is 4.28 ton ha ${ }^{-1}$ (BPS, 2018). This low productivity can be overcome by using advanced technology to meet the demand for Chili commodities throughout the year.

Advanced technology research has been carried out related to the development of Precision Agriculture. One 
of the precision technologies that have been developed for vegetable crops is fertigation through drip irrigation. Fertigation is the application of fertilization together with water irrigation (Chauhdary et al., 2018). Through fertigation technology, the composition and rate of nutrients can be adjusted according to the physiological development of the plant, so that in addition to more efficient use of nutrients, it also affects plant growth and yield. Fertigation applications could make nutrient use more efficient by $25-40 \%$ for horticultural crops. They were compared to conventional fertilization methods, along with additional income in the range of $10-15 \%$ (Pitono, 2018). Chaudhary

Drip irrigation, also known as micro-irrigation or trickle irrigation, is a method of slowly applying water directly to the root zone. The efficiency of water use in drip irrigation is more than $90 \%$, where the application of sprinkler irrigation is only 50 to $70 \%$. The high efficiency of drip irrigation is caused by 1) water will wet the soil before it is lost due to evaporation or runoff; 2) application of water is only carried out in the root zone, not in the entire soil layer; 3) suppress weed growth; 4) reduce the contact of irrigation water with plant crowns so as to reduce the possibility of pest infestation (Reddy et al., 2017). There was no difference in yield between fertigation via subsurface drip irrigation and through surface drip irrigation using plastic mulch (Wu et al., 2019)

In fertigation, fertilizer can be applied before or at planting (preplant), or with drip irrigation, or combination between preplant with drip irrigation (split). According to rate recommendations (Mounika et al., 2018), fertilizer application by fertigation to red chili plants is carried out with $100 \% \mathrm{P}$ fertilizer at planting, $\mathrm{N}$ fertilization is carried out twice a week as much as 18\% (2-4 MST), 14\% (5-7 MST), 20\% (7-8 MST), and 48\% (9-20 MST), while for K fertigation along with $\mathrm{N}$ as much as $14 \%$ (2-4 MST), $16 \%$ (5-7 MST), 22\% (7-8 MST), and $48 \%$ (9-20 MST).

Nitrogen $(\mathrm{N})$ is an essential prerequisite for almost all crops and is ideal for fertigation due to its complete dissolution in irrigation water. Urea, ammonium nitrate $\left(\mathrm{NH}_{4} \cdot \mathrm{NO}_{3}\right)$, calcium nitrate $\left(5 \mathrm{Ca}\left[\mathrm{NO}_{3}\right]_{2} . \mathrm{NH}_{4} \mathrm{NO}_{3}\right)$, potassium nitrate $\left(\mathrm{KNO}_{3}\right)$, and ammonium sulfate $\left(\left[\mathrm{NH}_{4}\right]_{2} \mathrm{SO}_{4}\right)$ are some of the examples of $\mathrm{N}$-containing sources. The $\mathrm{N}$ fertilizers are extensively used to prepare single or multi-nutrient fertilizer solutions (Fares and Abas, 2009)

Increasing the yield of paprika can be done by fertilizing it together with drip irrigation. Nitrogen Fertilizer Use Efficiency increases with the application of $\mathrm{N}$ fertilizers through drip irrigation when compared to conventional methods through furrow irrigation. The application of irrigation through drip irrigation every two days gives better results when compared to scheduling using a tensiometer (Tanaskovik, 2016). The application of fertilizers by fertigation provides yields and income when compared to the application of fertilizers by soil drench of lowland cauliflower (Sofian and Susila, 2018).

The use of polyethylene mulch or plastic mulch has been used in pepper cultivation since the early 1960s. The benefits of using polyethylene mulch are increasing yields, maintaining soil moisture, inhibiting weed growth, reducing nutrient losses and preventing soil compaction (Bosland and Votata, 2012). Water and nutrients are two important inputs in agriculture. Efficient water and nutrient management are essential to improve productivity and maintain good quality environmental conditions. Drip irrigation is one of the most efficient and widely used irrigation methods in the world (Jat et al., 2011). The use of drip irrigation combined with polyethylene mulch can increase the yield (Mehanna et al., 2016). This study aims to find out the best fertilizer application methods through drip irrigation and obtain a nitrogen fertilizer source that can increase the yield of polyethylene mulched chili.

\section{MATERIALS AND METHODS}

\section{Fertilizer Application Methods for Chili Fertigation}

This study was conducted from June to December 2016 at IPB University Research Station, Cikarawang, Bogor, (-6.547928S; 106.732102E), $250 \mathrm{~m}$ above sea level with Inceptisols soil type. Soil pH 5.14, C-organic 1.43\% (low), total N $0.19 \%$ ppm (low), total P 745.48 ppm (very high), and total K 212,12 ppm (very high). Four weeks of transplant age of Nirmala F1 Chili variety were used in this study. The treatments were: split application $(40 \% \mathrm{~N}$ and $\mathrm{K}_{2} \mathrm{O}$, and $100 \% \mathrm{P}_{2} \mathrm{O}_{5}$ before planting (pre-plant) and $60 \%$ of $\mathrm{N}$ and $\mathrm{K}_{2} \mathrm{O}$ were applied $10 \%$ every week for six weeks through drip irrigation; drip application $\left(100 \% \mathrm{~N}\right.$ and $\mathrm{K}_{2} \mathrm{O}$ were applied $16.7 \%$ every week for six weeks through drip irrigation); conventional fertilizing treatment (not using drip irrigation) as a check treatment, $100 \% \mathrm{P}, 40 \% \mathrm{~N}$ and $\mathrm{K}_{2} \mathrm{O}$ were applied as pre-plant, and $60 \% \mathrm{~N}$ and $\mathrm{K}_{2} \mathrm{O}$ applied at 3 and 6 weeks after planting. Each treatment was arranged in RCBD with four replications so that there were 12 experimental units with a plot size of $1.5 \mathrm{~m} \times 5 \mathrm{~m}$ with a plant spacing of $50 \mathrm{~cm} \times 50 \mathrm{~cm}$ (double row). Ten samples were observed for each experimental unit. The standard fertilization rate is $300 \mathrm{~kg} \mathrm{~N}^{-1}$ from urea dose $(46 \% \mathrm{~N})$, $300 \mathrm{~kg} \mathrm{P}_{2} \mathrm{O}_{5}$ ha $^{-1}$ from SP-36 $\left(36 \% \mathrm{P}_{2} \mathrm{O}_{5}\right), 250 \mathrm{~kg} \mathrm{~K}_{2} \mathrm{O}$ ha $^{-1}$ from $\mathrm{KCl}\left(60 \% \mathrm{~K}_{2} \mathrm{O}\right)$ (Heryani et al., 2013).

\section{Nitrogen Fertilizer Source for Chili Fertigation}

The experiment was conducted at IPB University Research Station, Cikarawang, Bogor, at an altitude of 250 $\mathrm{m}$ above sea level with Inceptisols soil type. This research was conducted from March 2017 until October 2017. Four weeks of transplant age of Nirmala F1 Chili variety were used in this study. Three $\mathrm{N}$-source treatments were: $\mathrm{N}$ fertilizer treatment from urea fertilizer $(46 \% \mathrm{~N}), \mathrm{N}$ fertilizer treatment from ZA fertilizer $(21 \% \mathrm{~N})$, and fertilizer source treatment $\mathrm{N}$ derived from NPK fertilizer (16-16-16). Each treatment was arranged in RCBD with four replications so that there were 12 experimental units with a plot size of 1.5 $\mathrm{m} \times 5 \mathrm{~m}$ with a plant spacing of $50 \mathrm{~cm} \times 50 \mathrm{~cm}$ (double row). Ten samples were observed for each experimental unit. The standard fertilization rate was $300 \mathrm{~kg} \mathrm{~N} \mathrm{ha}^{-1}$ from

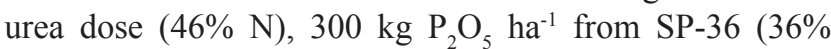
$\left.\mathrm{P}_{2} \mathrm{O}_{5}\right), 250 \mathrm{~kg} \mathrm{~K}_{2} \mathrm{O}$ ha $^{-1}$ from $\mathrm{KCl}^{2}\left(60 \% \mathrm{~K}_{2} \mathrm{O}\right)$ (Heryani et 
$a l ., 2013)$. Fertilization is done by split application method, $40 \%$ applied at preplant and $60 \%$ after transplanting through fertigation. Sixty percentage of the total fertilizer rate applied 6\% per week for ten weeks. Standard fertilization rate were $237.07 \mathrm{~kg} \mathrm{~N} \mathrm{ha}^{-1}, 108.33 \mathrm{~kg} \mathrm{P}_{2} \mathrm{O}_{5} \mathrm{ha}^{-1}$, and 188.4 $\mathrm{kg} \mathrm{K}_{2} \mathrm{O} \mathrm{ha}{ }^{-1}$ (Alviana and Susila, 2009).

\section{Drip Irrigation System for Fertigation}

The irrigation system equipment used is as follows 1 . The Head Unit consists of a 1,000 liter water tank, a 350-watt electric pump, a 3/4 inch disk filter, a 3/4 inch screen filter, a water meter, 3/4 inch Fertilizer Injector; 2. The Infield Unit consists one inch PVC pipe as the mainline, $16 \mathrm{~mm}$ $\mathrm{PE}$ as Sub main and Lateral, and a drip tape with an emitter distance of $50 \mathrm{~cm}$ and a flow rate of one 1 hour $^{-1}$. Irrigation water application volume was applied to 2 litters per plant/ day. Fertigation was applied to $60 \% \mathrm{~N}$ and $\mathrm{P}$ fertilizer, $10 \%$ for six weeks at the First experiment dan $6 \%$ for ten weeks in the second experiment. Fertilizer application for fertigation was presented in Table 1.

\section{Crop Management}

Nirmala F1 chili variety was shown in the seedling tray with planting media in the form of a mixture of sand, compost, and charcoal husk (1:1:1). Transplanting was done at six weeks after seedling. Cow manure was applied to 20 tons $\mathrm{ha}^{-1}$, together with a preplant fertilizer application on the bed. Dripnet line was installed in the middle of the bed, then covered by polyethylene mulched. Irrigation was applied at \pm 1.5 liters per plant per day. Plant pest and disease control were done when the plant begins to experience symptoms of insect attack and disease by spraying pesticide with the active ingredient of deltamethrin $25 \mathrm{~g} \mathrm{~L}^{-1}$ for aphid (Myzus persicae) pests, grasshoppers (Valanga sp.) and thrips (Thrips parvisipinus), bactericidal streptomycin 2\% sulfate for anthracnose disease, and fusarium wilt disease and Phytophthora capsici foliar sprayed with chlorpyrifos 200 $\mathrm{g} \mathrm{L}^{-1}$. Harvesting was done when the plant has reached the fully ripe fruit. The ripe fruit is characterized by bright red fruit up to $80 \%$ of the fruit. Harvesting was done at intervals every 5-7 days.

Table 1. Fertilizer application for the first and second experiments

\begin{tabular}{|c|c|c|c|c|c|c|c|c|c|c|c|}
\hline \multicolumn{5}{|c|}{ The first experiment (g per $7.5 \mathrm{~m}^{2}$ ) } & \multicolumn{7}{|c|}{ The second experiment (g per $7.5 \mathrm{~m}^{2}$ ) } \\
\hline Treatments & $\%$ & Urea & SP36 & $\mathrm{KCL}$ & Treatment & $\%$ & Urea & $\mathrm{ZA}$ & NPK & SP36 & KCL \\
\hline \multicolumn{5}{|c|}{ Split (preplant+drip) fertigation } & \multicolumn{7}{|c|}{ Split (preplant+drip) fertigation } \\
\hline a. Pre-plant & 40 & 196 & 625 & 150 & Pre-plant & 40 & 155 & 339 & 474 & 225 & 155 \\
\hline b. Drip & & & & & Drip & & & & & & \\
\hline Week-1 & 10 & 49 & 0 & 38 & Week-1 & 6 & 23 & 51 & 71 & 0 & 17 \\
\hline Week-2 & 10 & 49 & 0 & 38 & Week-2 & 6 & 23 & 51 & 71 & 0 & 17 \\
\hline Week-3 & 10 & 49 & 0 & 38 & Week-3 & 6 & 23 & 51 & 71 & 0 & 17 \\
\hline Week-4 & 10 & 49 & 0 & 38 & Week-4 & 6 & 23 & 51 & 71 & 0 & 17 \\
\hline Week-5 & 10 & 49 & 0 & 38 & Week-5 & 6 & 23 & 51 & 71 & 0 & 17 \\
\hline Week-6 & 10 & 49 & 0 & 38 & Week-6 & 6 & 23 & 51 & 71 & 0 & 17 \\
\hline Drip fertigation & & & & & Week-7 & 6 & 23 & 51 & 71 & 0 & 17 \\
\hline Week-1 & 16.7 & 82 & 0 & 63 & Week-8 & 6 & 23 & 51 & 71 & 0 & 17 \\
\hline Week-2 & 16.7 & 82 & 0 & 63 & Week-9 & 6 & 23 & 51 & 71 & 0 & 17 \\
\hline Week-3 & 16.7 & 82 & 0 & 63 & Week-10 & 6 & 23 & 51 & 71 & 0 & 17 \\
\hline Week-4 & 16.7 & 82 & 0 & 63 & & & & & & & \\
\hline Week-5 & 16.7 & 82 & 0 & 63 & & & & & & & \\
\hline Week-6 & 16.7 & 82 & 0 & 63 & & & & & & & \\
\hline \multicolumn{12}{|c|}{ Conventional (preplant+soil drench) } \\
\hline \multicolumn{12}{|l|}{ Pre-plant } \\
\hline a. Pre-plant & 40 & 196 & 625 & 260 & & & & & & & \\
\hline \multicolumn{12}{|l|}{ b. Soil drench } \\
\hline Week-3 & 30 & 147 & 0 & 113 & & & & & & & \\
\hline Week-6 & 30 & 147 & 0 & 113 & & & & & & & \\
\hline Rate $\left.\mathrm{kg} \mathrm{ha}^{-1 *}\right)$ & 100 & 652 & 833 & 500 & & 100 & 515 & 1129 & 1580 & 300 & 376 \\
\hline
\end{tabular}

Note: Split $=100 \% \mathrm{P}_{2} \mathrm{O}_{5}+40 \% \mathrm{~K}_{2} \mathrm{O}+40 \% \mathrm{~N}$ (preplant) \& $60 \% \mathrm{~K}_{2} \mathrm{O}+60 \% \mathrm{~N}$ (drip). Drip $=100 \% \mathrm{P}_{2} \mathrm{O}_{5}$ (preplant) \& $100 \% \mathrm{~N}$ and $\mathrm{K}_{2} \mathrm{O}_{5}$ (drip). Conventional $=100 \% \mathrm{P}_{2} \mathrm{O}_{5}+40 \% \mathrm{~K}_{2} \mathrm{O}+40 \% \mathrm{~N}$ (preplant) \& $60 \% \mathrm{~K}_{2} \mathrm{O}+60 \% \mathrm{~N}$ (Soil Drench), ${ }^{*}$ ) Fertilizer rate per hectare based on Alviana and Susila (2009) 


\section{Observation and Data Analysis}

Observations were made on plant height, $50 \%$ anthesis, 50\% fruit maturity, fruit weight per bed $\left(7.5 \mathrm{~m}^{2}\right)$, and yield prediction per ha. The observation was conducted in 10 randomly selected sample plants in each replication from one to ten weeks for plant height $(\mathrm{cm})$. Observations variables of generative phase plants include: age of flowering (50\% anthesis) and time of ripe fruit (50\% fruit maturity) in days. The crop yield components observed include fruit weight and grade per bed, fruit weight prediction per ha. The $\mathrm{F}$ test analyzed the observed data at $\alpha=5 \%$. If there is a significant difference, proceed with further tests by the Duncan Multiple Range Test (DMRT) test at $\alpha=5 \%$.

\section{RESULTS AND DISCUSSION}

\section{Plant Height}

Fertilization application of all treatments did not significantly affect chili height until three weeks after transplanting. The significant effect occurred between 4 to 6 weeks after transplanting. The plant height obtained by split fertigation was not significantly different from the drip fertigation. Spit and drip fertigation plant height was higher than the conventional application. From the beginning of growth until the age of 3 weeks, the plant height increase is still slow, so that the effect of treatment has not been seen. Starting with fast growth at four weeks of age, the plants' response to the treatment has occurred. Hamdani et al. (2019) showed that Santika F1 chili was grown on inceptisol with $40 \% \mathrm{~N}$ and $\mathrm{K}$ applied preplant, and $60 \%$ applied through drip irrigation (split) resulted in 12.26 ton $\mathrm{ha}^{-1}$ yield from 14 ton $\mathrm{ha}^{-1}$ potential yield. The source of Nitrogen fertilizer, however, all treatment has no significant effect on chili plant height. The result of fertilizer application on plant height is presented in Table 2.

\section{Anthesis and Maturity}

Chili plants start flowering at the age of 2 weeks after planting, but some flowers dropped. The days of anthesis and days of maturity had a significant response to the three fertigation methods. Conventional fertilization resulted in later anthesis or fruit maturity time than those with split and drip fertigation. This evidence indicates that drip and split fertigation can increase nutrient absorption and utilization. So the time of the flower emergence on the conventional treatment slightly shorter than with conventional fertilization. There was no significant effect of nitrogen sources on days of anthesis and days of maturity. The impact of fertilization application on days of anthesis fruit maturity Table 3

\section{Plant Yield}

Fertigation methods significantly affect fruit weight and total yield per bed $\left(7.5 \mathrm{~m}^{2}\right)$ from first to the 5 th harvesting. Drip fertigation resulted in a total weight of fruit per bed of 3,458.33 $\mathrm{g}$ for five times harvesting, and it was higher than the conventional treatment of 924.33 g. According to Hebbar et al. (2002), 100\% water-soluble fertilizer treatment applied through drip irrigation increased yield significantly compared to other fertilization methods. However, a Nitrogen source did not significantly affect fruit weight and total fruit weight per bed for all eight harvesting times (Table 4).

The fertigation method significantly affects the total marketable yield per bed $\left(7.5 \mathrm{~m}^{2}\right)$ and per hectare. The split

Table 2. Effect of fertilizer application methods on chili plant height from1 to 10 weeks after transplanting

\begin{tabular}{|c|c|c|c|c|c|c|c|c|c|c|}
\hline \multirow{2}{*}{ Treatment } & \multicolumn{10}{|c|}{ Plant height $(\mathrm{cm})$ at 1-10 weeks after transplanting (WAT) } \\
\hline & 1 & 2 & 3 & 4 & 5 & 6 & 7 & 8 & 9 & 10 \\
\hline \multicolumn{11}{|c|}{ First experiment } \\
\hline Split & 20.81 & 23.82 & 27.60 & $27.79 \mathrm{a}$ & $44.34 \mathrm{a}$ & $55.58 \mathrm{a}$ & $62.76 \mathrm{a}$ & $69.88 \mathrm{a}$ & $75.99 a$ & $78.99 \mathrm{a}$ \\
\hline Drip & 20.46 & 23.38 & 26.89 & $27.27 \mathrm{a}$ & $44.00 \mathrm{a}$ & $53.71 \mathrm{a}$ & $61.99 a$ & $67.41 \mathrm{a}$ & $72.18 \mathrm{a}$ & $75.11 \mathrm{a}$ \\
\hline Conventional & 20.29 & 22.41 & 23.99 & $21.79 \mathrm{~b}$ & $26.71 b$ & $27.66 \mathrm{~b}$ & $34.43 b$ & $44.42 b$ & $51.61 \mathrm{~b}$ & $55.82 b$ \\
\hline Response & ns & ns & ns & $*$ & $* *$ & $* *$ & $* *$ & $* *$ & $* *$ & $* *$ \\
\hline \multicolumn{11}{|c|}{ Second experiment } \\
\hline Urea & 20.40 & 23,00 & 26.50 & 31.80 & 36.40 & 42.30 & 46.90 & 52.80 & 56.70 & 60.00 \\
\hline ZA & 17.00 & 19.00 & 22.30 & 30.90 & 32.50 & 39.60 & 46.20 & 53.30 & 57.80 & 65.70 \\
\hline NPK & 19.90 & 22.00 & 25.70 & 27.60 & 35.80 & 42.80 & 47.40 & 54.40 & 59.70 & 65.20 \\
\hline Response & $\mathrm{ns}$ & ns & ns & $\mathrm{ns}$ & ns & ns & ns & $\mathrm{ns}$ & ns & ns \\
\hline
\end{tabular}

Note: Split $=100 \% \mathrm{P}_{2} \mathrm{O}_{5}+40 \% \mathrm{~K}_{2} \mathrm{O}+40 \% \mathrm{~N}$ (preplant) \& $60 \% \mathrm{~K}_{2} \mathrm{O}+60 \% \mathrm{~N}$ (drip). Drip $=100 \% \mathrm{P}_{2} \mathrm{O}_{5}$ (preplant) \& $100 \% \mathrm{~N}$ and $\mathrm{K}_{2} \mathrm{O}_{5}$ (drip). Conventional $=100 \% \mathrm{P}_{2} \mathrm{O}_{5}+40 \% \mathrm{~K}_{2} \mathrm{O}+40 \% \mathrm{~N}$ (preplant) \& $60 \% \mathrm{~K}_{2} \mathrm{O}+60 \% \mathrm{~N}$ (soil drench). *The values followed by the same letters within the same column are not significantly different at the $5 \%$ level of DMRT; ns = not significant; *P $<0.05 ; * * \mathrm{P}<$ 0.01 
Table 3. Effect of fertilizer application methods on chili days of anthesis and fruit maturity

\begin{tabular}{lcc}
\hline Treatments & $50 \%$ anthesis (days) & $50 \%$ fruit maturity (days) \\
\hline & First experiment & $81.50 \mathrm{~b}$ \\
Split & $30.00 \mathrm{~b}$ & $81.50 \mathrm{~b}$ \\
Drip & $30.75 \mathrm{~b}$ & $88.75 \mathrm{a}$ \\
Conventional & $42.5 \mathrm{a}$ & $* *$ \\
\hline Response & $* *$ & 75.25 \\
\hline & Second experiment & 77.00 \\
Urea & 31.50 & 75.25 \\
NPK & 31.50 & $\mathrm{~ns}$ \\
\hline Response & 29.75 & $\mathrm{~ns}$ \\
\hline
\end{tabular}

Note: Split $=100 \% \mathrm{P}_{2} \mathrm{O}_{5}+40 \% \mathrm{~K}_{2} \mathrm{O}+40 \% \mathrm{~N}$ (preplant) \& $60 \% \mathrm{~K}_{2} \mathrm{O}+60 \% \mathrm{~N}$ (drip). Drip $=100 \% \mathrm{P}_{2} \mathrm{O}_{5}$ (preplant) \& $100 \% \mathrm{~N}_{\text {and }} \mathrm{K}_{2} \mathrm{O}_{5}$ (drip). Conventional $=100 \% \mathrm{P}_{2} \mathrm{O}_{5}+40 \% \mathrm{~K}_{2} \mathrm{O}+40 \% \mathrm{~N}$ (preplant) $\& 60 \% \mathrm{~K}_{2} \mathrm{O}+60 \% \mathrm{~N}$ (soil drench). *The values followed by the same letters within the same column are not significantly different at the $5 \%$ level of DMRT; ns = not significant; *P $<0.05 ; * * \mathrm{P}<$ 0.01

application did notsignificantly different from drip fertigation on marketable yield per bed or per hectare; however, both yields were higher than those with conventional fertilization. In the split treatment, $40 \% \mathrm{~N}$ and $\mathrm{K}$ were given before planting; meanwhile, all $\mathrm{N}$ and $\mathrm{K}$ were through fertigation in the Drip treatment. In split, the plants obtained $\mathrm{N}$ and $\mathrm{K}$ nutrients as growth starters, but this condition did not affect the yield per plot of chili. Split and drip resulted in a higher fruit weight than conventional. The amount of irrigation water in the conventional method is likely lower than the other two treatments. In conventional methods, fertilizers are applied three times during the growing season. Locascio et al. (1989) showed that the yield of tomato was greater with $60 \%$ drip used $\mathrm{N}$ and $\mathrm{K}$ (split fertigation) than with preplant used N and K (100\% broadcast before planting). The total marketable yield per bed or hectare was not affected by Nitrogen sources (Table 5 and 6).

The productivities of Nirmala F1 chili variety in this study were 3.46 ton $\mathrm{ha}^{-1}$ (first experiment), and 2.46 ton ha-1. (second experiment), both productivities were lower than national productivity (4.28 ton $\left.\mathrm{ha}^{-1}\right)$. Some contributing factors include 1 . The soil analysis results showed that the total soil $\mathrm{P}$ content was $745.48 \mathrm{ppm}$ (very high), and the total $\mathrm{K}$ content was $212,12 \mathrm{ppm}$ (very high). At the same time, the fertilization recommendations in this experiment were not determine based on soil analysis. Fertilization rate recommendations were taken from Heryani et al. (2013) and Alviana and Susila (2009); 2. Another factor is the possible

Table 4. Effect of fertilizer application methods on chili fruit weight per bed $\left(7.5 \mathrm{~m}^{2}\right)$

\begin{tabular}{|c|c|c|c|c|c|c|c|c|c|}
\hline \multirow{2}{*}{ Treatments } & \multicolumn{9}{|c|}{ Fruit weight per bed (g per $\left.7.5 \mathrm{~m}^{2}\right)$} \\
\hline & Harvest 1 & Harvest 2 & Harvest 3 & Harvest 4 & Harvest 5 & Harvest 6 & Harvest 7 & Harvest 8 & Total \\
\hline \multicolumn{10}{|c|}{ First experiment } \\
\hline Split & $328.69 \mathrm{a}$ & $514.50 \mathrm{a}$ & $795.50 \mathrm{a}$ & $611.25 \mathrm{a}$ & $1058.50 \mathrm{a}$ & - & - & - & $3,308.44 a$ \\
\hline Drip & $317.90 \mathrm{a}$ & $561.69 \mathrm{a}$ & $716.00 \mathrm{a}$ & $753.25 \mathrm{a}$ & $1109.50 \mathrm{a}$ & - & - & - & $3,458.33 \mathrm{a}$ \\
\hline Conventional & $44.50 \mathrm{~b}$ & $76.67 b$ & $111.36 \mathrm{~b}$ & $151.30 \mathrm{~b}$ & $540.50 \mathrm{~b}$ & & & & $924.33 b$ \\
\hline Response & $* *$ & $* *$ & $* *$ & $* *$ & $*$ & - & - & - & $* *$ \\
\hline \multicolumn{10}{|c|}{ Second experiment } \\
\hline Urea & 213.89 & 230.70 & 58.35 & 103.32 & 334.76 & $721.20 \mathrm{a}$ & 495.20 & 198.51 & $2,355.80$ \\
\hline ZA & 228.07 & 255.60 & 119.01 & 137.08 & 502.09 & 815.40 & 575.30 & 262.96 & $2,895.50$ \\
\hline NPK & 198.63 & 237.70 & 110.40 & 110.18 & 391.26 & 909.90 & 495.20 & 319.42 & $2,878.90$ \\
\hline Response & $\mathrm{ns}$ & ns & ns & ns & ns & ns & ns & $\mathrm{ns}$ & ns \\
\hline
\end{tabular}

Note: Split $=100 \% \mathrm{P}_{2} \mathrm{O}_{5}+40 \% \mathrm{~K}_{2} \mathrm{O}+40 \% \mathrm{~N}$ (preplant) \& $60 \% \mathrm{~K}_{2} \mathrm{O}+60 \% \mathrm{~N}$ (drip). Drip $=100 \% \mathrm{P}_{2} \mathrm{O}_{5}$ (preplant) \& $100 \% \mathrm{~N}$ and $\mathrm{K}_{2} \mathrm{O}_{5}$ (drip). Conventional $=100 \% \mathrm{P}_{2} \mathrm{O}_{5}+40 \% \mathrm{~K}_{2} \mathrm{O}+40 \% \mathrm{~N}$ (preplant) \& $60 \% \mathrm{~K}_{2} \mathrm{O}+60 \% \mathrm{~N}$ (soil drench). *The values followed by the same letters within the same column are not significantly different at the $5 \%$ level of DMRT; ns $=$ not significant; $* \mathrm{P}<0.05 ; * * \mathrm{P}<$ 0.01 
lack of volume of watering. The low watering impact can be seen from the lower yields in the conventional method where the fertilizer is soil drench three times only, however ten times for drip and split fertigation. For further research, fertilizer recommendations base on soil analysis was needed.

Meanwhile, in the second experiment, the nitrogen source had no significant effect. NPK contains additional $\mathrm{P}$ and $\mathrm{K}$, but the $\mathrm{P}$ and $\mathrm{K}$ content available, the land is very high, so the plants do not give a response. The second experiment was carried out during the dry season. It was seen that the irrigation volume had a significant impact on productivity. For drip irrigation applications, it is necessary to carry out an in-depth study of chili plants' daily water requirements according to the plant growth phase. Labor cost analysis also needs to be evaluated for future adoption of fertigation technology for vegetable crop management.

Table 5. Effect of fertilizer application methods on chili total fruit weight grade 1, 2, 3, 4, and marketable weight per bed $\left(7.5 \mathrm{~m}^{2}\right)$

\begin{tabular}{|c|c|c|c|c|c|}
\hline \multirow[b]{2}{*}{ Treatment } & \multicolumn{5}{|c|}{ Fruit weight per bed $\left(\mathrm{g}\right.$ per $\left.7.5 \mathrm{~m}^{2}\right)$} \\
\hline & $\begin{array}{c}\text { Grade } \\
1 \\
\end{array}$ & $\begin{array}{c}\text { Grade } \\
2 \\
\end{array}$ & $\begin{array}{c}\text { Grade } \\
3 \\
\end{array}$ & $\begin{array}{c}\text { Grade } \\
4 \\
\end{array}$ & $\begin{array}{c}\text { Marketable yield } \\
(1+2+3)\end{array}$ \\
\hline \multicolumn{6}{|c|}{ First experiment } \\
\hline Split & $160.10 \mathrm{a}$ & $271.73 \mathrm{a}$ & $183.25 \mathrm{a}$ & 24.37 & $615.08 \mathrm{a}$ \\
\hline Drip & $145.71 \mathrm{a}$ & $290.02 \mathrm{a}$ & $216.11 \mathrm{a}$ & 37.63 & $651.85 \mathrm{a}$ \\
\hline Conventional & $58.44 \mathrm{~b}$ & $75.50 \mathrm{~b}$ & $53.21 \mathrm{~b}$ & 16.43 & $185.64 \mathrm{~b}$ \\
\hline Response & $* *$ & $* *$ & $* *$ & $\mathrm{~ns}$ & $* *$ \\
\hline \multicolumn{6}{|c|}{ Second experiment } \\
\hline Urea & 202.10 & $1,167.70$ & 782.80 & 172.25 & $2,152.60$ \\
\hline $\mathrm{ZA}$ & 326.60 & $1,504.90$ & 842.40 & 192.15 & $2,673.80$ \\
\hline NPK & 330.50 & $1,456.30$ & 851.70 & 205.43 & $2,638.40$ \\
\hline Response & ns & $\mathrm{ns}$ & ns & $\mathrm{ns}$ & $\mathrm{ns}$ \\
\hline
\end{tabular}

Note: Split $=100 \% \mathrm{P}_{2} \mathrm{O}_{5}+40 \% \mathrm{~K}_{2} \mathrm{O}+40 \% \mathrm{~N}$ (preplant) \& $60 \% \mathrm{~K}_{2} \mathrm{O}+60 \% \mathrm{~N}$ (drip). Drip $=100 \% \mathrm{P}_{2} \mathrm{O}_{5}$ (preplant) \& $100 \% \mathrm{~N}$ and $\mathrm{K}_{2} \mathrm{O}_{5}$ (drip). Conventional $=100 \% \mathrm{P}_{2} \mathrm{O}_{5}+40 \% \mathrm{~K}_{2} \mathrm{O}+40 \% \mathrm{~N}$ (preplant) \& $60 \% \mathrm{~K}_{2} \mathrm{O}+60 \% \mathrm{~N}$ (soil drench). *The values followed by the same letters within the same column are not significantly different at the $5 \%$ level of DMRT; ns = not significant; $* \mathrm{P}<0.05 ; * * \mathrm{P}<$ 0.01

Table 6. Effect of fertilizer application methods on chili total weight (ton ha-1)

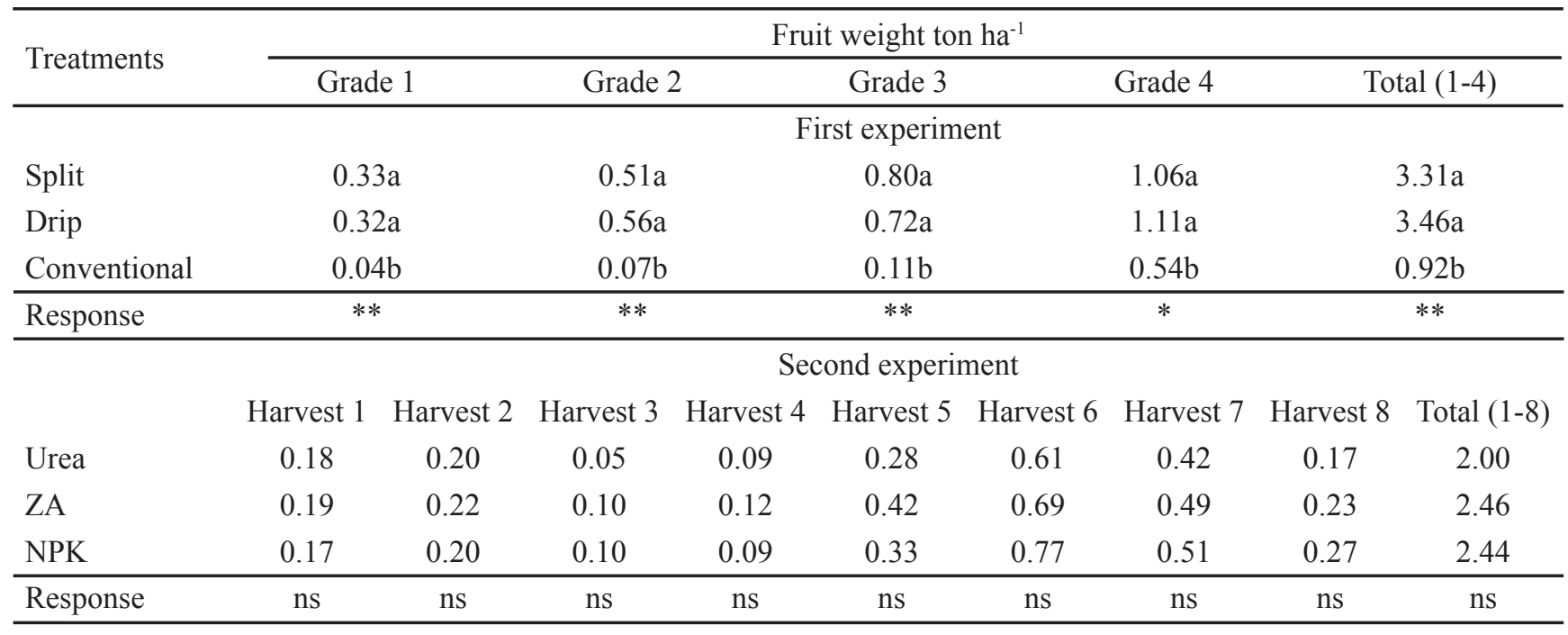

Note: Split $=100 \% \mathrm{P}_{2} \mathrm{O}_{5}+40 \% \mathrm{~K}_{2} \mathrm{O}+40 \% \mathrm{~N}$ (preplant) \& $60 \% \mathrm{~K}_{2} \mathrm{O}+60 \% \mathrm{~N}$ (drip). Drip $=100 \% \mathrm{P}_{2} \mathrm{O}_{5}$ (preplant) \& $100 \% \mathrm{~N}^{2}$ and $\mathrm{K}_{2} \mathrm{O}_{5}$ (drip). Conventional $=100 \% \mathrm{P}_{2} \mathrm{O}_{5}+40 \% \mathrm{~K}_{2} \mathrm{O}+40 \% \mathrm{~N}$ (preplant) \& $60 \% \mathrm{~K}_{2} \mathrm{O}+60 \% \mathrm{~N}$ (soil drench). *The values followed by the same letters within the same column are not significantly different at the $5 \%$ level of DMRT; ns $=$ not significant; $* \mathrm{P}<0.05 ; * * \mathrm{P}<$ 0.01 


\section{CONCLUSIONS}

Split (40\% preplant $+60 \%$ drip) and drip (100\% drip) of Nitrogen and Potassium fertilizer application through drip irrigation resulted in significantly higher plant height and yield than conventional (33\% three times soil drench) fertilization. There is no difference between the response of plant chili growth and the yield on urea $(45 \% \mathrm{~N}), \mathrm{ZA}$ $(21 \% \mathrm{~N})$, and $\mathrm{NPK}\left(15-15-15 \%, \mathrm{~N}-\mathrm{P}_{2} \mathrm{O}_{5}, \mathrm{~K}_{2} \mathrm{O}\right)$ as a fertilizer sources for fertigation.

\section{REFERENCES}

Alviana,V.F., A.D. Susila. 2009. Optimasi dosis pemupukan pada budidaya cabai (Capsicum annum L.) menggunakan irigasi dan mulsa polyethylene. J. Agron. Indonesia 37:28-33.

BPS. 2018. Statistik Tanaman Sayuran dan Buah-buahan Semusim Indonesia 2017. Badan Pusat Statistik Indonesia, ID.

Bosland, P.W., E.J. Votava. 2012. Peppers Vegetable and Spice Capsicums 2nd Edition. CABI, Cambridge, US.

Chauhdary, J.N., A. Bakhsh, M. Arshad, M. Maqsood. 2018. Effect of different irrigation and fertigation strategies on corn production under drip irrigation. Pakistan J. Agric. Sci. 54:855-863.

Fares, A., A. Abas. 2009. Irrigation Systems and Nutrient Sources for Fertigation. Cooporative Extension Publication No. SCM 25. Coolege Tropical Agriculture, Unibersity og Hawaii. Manoa, US.

Hamdani, K.K., A.D. Susila, Purwono, K.Suketi. 2019. Potassium Sources and Rates for Drip Irrigated Polyethylene Mulched Chili Pepper. J. Trop. Crop Sci. 6:89-97.

Hebbar, S.S., B.K. Ramachandrappa, H.V. Nanjappa, M. Prabhakar. 2002. Studies on NPK drip fertigation in field-grown tomato (Lycopersicon esculentum Mill.). Europ. J. Agronomy 21:117-127.

Heryani, N., B. Kartiwa, Y. Sugiarto, T. Handayani. 2013. Pemberian mulsa dalam budidaya cabai rawit di lahan kering: dampaknya terhadap hasil tanaman dan aliran permukaan. J. Agron. Indonesia 41:147-153.

Jat, R.A., S.P. Wani, K.L. Sahrawat, P. Singh, B.L. Dhaka. 2011. Fertigation in vegetable crops for higher productivity and resource use efficiency. Indian J. Fertilizer 7:22-37.

Locascio, S.J., S.M. Olson, F.M. Rhoads. 1989. Water quantity and time of $\mathrm{N}$ and $\mathrm{K}$ application for trickleirrigated tomatoes. J. Amer. Soc. Hort. Sci. 114:265268.

Mehanna, H.M., E.M. Okasha, M.A.A. Abdou 2016. Water Productivity and Fertilizer Use Efficiency of Drip Irrigated Maize. In M.R. Goyal (Ed.). Water and Fertigation Management in Micro Irrigation. Apple Academic Press, Oakville.

Mounika, D., M.U. Devi, V.P. Rao, K.A. Kumar, B. Prabakar. 2018. Impact of different $\mathrm{N}$ and $\mathrm{K}$ fertigation levels on yield attributes and total yield in paprika (Capsicum annuum L.) under drip fertigation. Int. J. Curr. Microbiol. Appl. Sci. 7:638-53.

Pitono, J. 2018. Prospek Fertigasi Untuk Pengelolaan Hara Pada Budidaya Lada. Perspektif 17:117-28.

Reddy, R., D. Santosh, K. Tiwari. 2017. Effect of drip irrigation and fertigation on growth, development and yield of vegetables and fruits. Int. J. Curr. Microbiol. Appl. Sci. 6:1471-83.

Sofian, M.E., A.D. Susila. 2018. Increasing cauliflower yields through fertigation. J. Trop. Crop Sci. 5:1-5.

Tanaskovik, V., O. Cukaliev, R.S. Kanwar, L.K. Heng, M. Markoski, V. Spalevic. 2016. Nitrogen fertilizer use efficiency of pepper as affected by irrigation and fertilization regime. Not. Bot. Horti. Agrobot. ClujNapoca 44:525-32

Wu, D., X. Xu, Y. Chen, H. Shao, E. Sokolowski, G. Mi. 2019. Effect of different drip fertigation methods on maize yield, nutrient and water productivity in two-soils in Northeast China. Agric. Water Manag. 213:200-211. 